\title{
KEGIATAN LOMBA MENDONGENG SEBAGAI PEMBENTUKAN KARAKTER SISWA SEKOLAH DASAR DI KOTA PALEMBANG
}

\author{
Mukhsin Patriansah'), Didiek Prasetya2), Havis Aravik ${ }^{3)}$ \\ 1)Prodi Desain Komunikasi Visual, Fakultas IImu Pemerintahan dan Budaya, Universitas Indo Global Mandiri, \\ Palembang, Sumatera Selatan, Indonesia \\ 2)Prodi Desain Komunikasi Visual, Politeknik PalComTech Palembang, Palembang, Sumatera Selatan, Indonesia \\ ${ }^{3)}$ Perbankan Syariah, Sekolah Tinggi Ekonomi dan Bisnis Syariah Indo Global Mandiri, Palembang, \\ Sumatera Selatan, Indonesia \\ Corresponding author : Mukhsin Patriansah \\ E-mail : mukhsin_dkv@uigm.ac.id
}

Diterima 21 Oktober 2021, Direvisi 03 Desember 2021, Disetujui 03 Desember 2021

\begin{abstract}
ABSTRAK
Pesatnya kemajuan teknologi informasi dengan segala kemudahannya dalam menggali informasiinformasi tidak diimbangi dengan penanaman etika dan moral sebagai pembentukan karakter seorang anak. Kemampuan anak dalam menyaring informasi yang diperoleh dapat dilakukan dengan cara memberikan pendidikan karakter kepada anak sedini mungkin, salah satunya adalah melalui kegiatan mendongeng. Kegiatan mendongeng atau bercerita bertujuan sebagai media untuk menanamkan etika dan moral kepada anak. Melalui dongeng anak mendapatkan suatu pelajaran berupa hikmah, kesimpulan dan pesan moral yang berbudi luhur tanpa merasa digurui. Di samping itu, sebuah cerita yang disampaikan lebih berkesan dari pada sebuah nasehat murni atau tutur kata yang diucapkan secara langsung. Pentingnya kegiatan mendongeng sebagai sarana pembentukan karakter anak, maka penulis bersedia menjadi juri pada kegiatan lomba mendongeng yang diselenggarakan oleh Forum Koordinasi Pengelolaan Daerah Aliran Sungai Sumatera Selatan (Forum Das Sumsel) dalam rangka memperingati hari penanggulangan degradasi lahan dan kekeringan tahun 2020 dan hari lingkungan hidup tahun 2020 di objek wisata alam Punti Kayu Kota Palembang. Di samping sebagai juri, penulis juga diberi kesempatan untuk memaparkan materi pelaksanaan dan capaian yang diperoleh dari kegiatan ini. Kegiatan lomba mendongeng ini diikuti oleh 20 peserta yang merupakan perwakilan dari Sekolah Dasar yang tersebar di Kota Palembang. Capaian yang diperoleh dari kegiatan ini adalah menciptakan kepekaan anak terhadap lingkungan mereka, menanamkan nilai kebaikan dalam kehidupan mereka sehari-hari.
\end{abstract}

Kata kunci: Pendidikan karakter; dongeng; edukatif; etika dan moral.

\begin{abstract}
The rapid advancement of information technology with all its convenience in digging up information is not balanced with the cultivation of ethics and morals as the formation of a child's character. The ability of children to filter the information obtained can be done by providing character education to children as early as possible, one of which is through storytelling activities. Storytelling or storytelling activities aim as a medium to instill ethics and morals in children. Through fairy tales, children get a lesson in the form of wisdom, conclusions and virtuous moral messages without feeling being taught. In addition, a story told is more memorable than a pure advice or spoken words directly. The importance of storytelling activities as a means of building children's character, the author is willing to be a jury in storytelling competitions organized by the South Sumatra River Basin Management Coordination Forum (Forum Das Sumsel) in commemoration of the day to overcome land degradation and drought in 2020 and the environmental day in 2020. 2020 at the Punti Kayu natural tourist attraction, Palembang City. In addition to being a judge, the author was also given the opportunity to explain the implementation material and the achievements obtained from this activity. This storytelling competition was attended by 20 participants who were representatives from elementary schools spread across the city of Palembang. The achievement obtained from this activity is to create children's sensitivity to their environment, to instill the value of goodness in their daily lives.
\end{abstract}

Keywords: Character education; fairy tales; educational; ethics and morals. 


\section{PENDAHULUAN}

Pendidikan mengemban suatu misi yang cukup kompleks, seperti perkembangan fisik, kesehatan, keterampilan, kecerdasan intelektual, sosial, hingga persoalan kepercayaan dan keimanan. Maka dari itu, tujuan pendidikan bukan hanya sekedar mencerdaskan intelektual saja melainkan menginternalisasikan nilai-nilai sosial dan solidaritas yang tercermin dalam kehidupan sehari-hari, sehingga membentuk manusia yang memiliki etika dan moral yang tinggi. Etika dan moral merupakan karakter yang harus ditanamkan kepada anak sejak usia dini. Pembentukan karakter seorang anak sangat berpengaruh terhadap prilaku sosial mereka sehari-hari.

Pada umumnya pendidikan di Indonesia sangat mengedepankan aspek pengembangan intelektual, artinya pendidikan hanya sebatas meningkatkan keilmuan dan kecerdasan seorang anak. Persoalan ini dapat dilihat banyaknya sekolah berlomba-lomba mendapatkan rating tertinggi dalam Ujian Akhir Nasional (UAS). Rating yang tinggi seakanakan sangat penting dan menjadi prioritas utama bagi setiap sekolah dan mengesampingkan etika dan moral siswa itu sendiri. Seperti yang diungkapkan oleh Sri Suwartini bahwa kualitas pendidikan di Indonesia selalu diukur dengan angka-angka, sehingga tidak mengherankan apabila dalam rangka mengejar target yang ditetapkan sebuah lembaga pendidikan terkadang melakukan kecurangan dan manipulasi (Suwartini, 2017, p. 20).

Pesatnya kemajuan teknologi informasi di era sekarang tidak diimbangi dengan penanaman etika dan moral sebagai pembentukan karakter seorang anak. Kemajuan teknologi informasi memiliki dampak yang sangat signifikan dalam berbagai aspek kehidupan manusia. Informasi dapat digali dan ditelusuri secara instan dengan menggunakan perangkat teknologi canggih. Tidak dapat dipungkiri, hal ini sangat mempengaruhi perkembangan anak dalam pembentukan karakter mereka. Sejak kecil anak-anak disuguhkan dengan berbagai produk teknologi informasi yang sudah menjadi menu mereka sehari-hari.

Kemudahan dalam mengakses informasi harus dibekali dengan pengetahuan anak terhadap informasi-informasi yang mengandung nilai edukasi. Kemampuan anak dalam menyaring informasi yang diperoleh dapat dilakukan dengan cara memberikan pendidikan karakter kepada anak sedini mungkin, khususnya anak yang berada pada jenjang pendidikan Sekolah Dasar. Karakter yang baik akan membentuk anak menjadi orang yang baik dan dapat membangun bangsa ini ke depannya.

Pendidikan karakter sangat penting bagi generasi muda, hal ini sangat disadari oleh pemerintah yang diamanatkan dalam UndangUndang Republik Indonesia pasal 3 Bab II Nomor 20 Tahun 2003 tentang Sistem Pendidikan Nasional yakni "Pendidikan Nasional berfungsi mengembangkan kemampuan dan membentuk karakter serta peradaban bangsa yang bermartabat dalam rangka mencerdaskan kehidupan bangsa, bertujuan untuk berkembangnya potensi peserta didik agar menjadi manusia yang beriman dan bertakwa kepada Tuhan Yang Maha Esa, berakhlak mulia, sehat, berilmu, cakap, kreatif, mandiri, dan menjadi warga negara yang demokratis serta bertanggung jawab".

Undang-undang tersebut dapat diartikan bahwa fungsi dan tujuan pendidikan nasional adalah membentuk akhlak yang mulia melalui pendidikan karakter, sehingga mampu membangun peradaban bangsa. Capaian ini harus diselenggarakan secara sistematis dan terukur di setiap jenjang pendidikan termasuk di jenjang pendidikan Sekolah Dasar. Dengan demikian, peserta didik memiliki etika, moral dan sopan santun dalam berinteraksi dengan masyarakat di sekitarnya.

Pendidikan karakter adalah suatu sistem penanaman nilai-nilai karakter kepada warga sekolah yang meliputi komponen pengetahuan, kesadaran, atau kemauan, dan tindakan untuk melaksanakan nilai-nilai tersebut, baik terhadap Tuhan YME, diri sendiri, sesama, lingkungan, maupun kebangsaan sehingga menjadi manusia insan kamil (Narwanti, 2011, p. 14). Pendidikan karakter berfungsi: (1) mengembangkan potensi dasar agar berhati baik, berpikir baik, dan berperilaku baik; (2) memperkuat dan memnbangun perilaku bangsa yang multikultur; dan (3) meningkatkan peradaban bangsa yang kompetitif dalam pergaulan dunia (Cahyani \& Raharjo, 2021, p. 54).

Pembentukan karakter seorang anak dapat dimulai dari Sekolah Dasar, yang mana pada jenjang ini seorang anak dibekali berbagai disiplin ilmu yang bersifat dasar mulai dari matematika, bahasa indonesia, pendidikan pancasila dan kewarganegaraan (PPKn), ilmu pengetahuan alam, ilmu pengetahuan sosial hingga keagamaan. Dari berbagai disiplin ilmu tersebut penanaman etika dan moral sebagai pembentukan karakter seorang anak hanya diberikan dimata pelajaran tertentu seperti PPKn dan agama. Oleh karena itu, diperlukan suatu upaya untuk menanamkan etika dan 
moral kepada anak sebagai salah satu pembentukan karakter mereka melalui kegitan lomba mendongeng.

Kegiatan mendongeng atau bercerita memiliki pengaruh penting terhadap pembentukan karakter anak-anak. Menurut Sukarno Budi Utomo dalam penelitiannya menjelaskan bahwa sampai detik ini bercerita atau mendongeng masih menjadi salah satu pilihan bagi orang tua dan guru dalam menanamkan budi pekerti pada anak (Utomo, 2019, p. 4). Selanjutnya, Sulistyorini dalam Siti Fadjryana Fitroh menjelaskan bahwa penyadaran nilai moral anak sangat tepat jika dilakukan melalui cerita atau dongeng sebab cerita atau dongeng merupakan media efektif untuk menanamkan nilai dan estetika kepada anak. Tujuan dari hal tersebut yakni melalui cerita dongeng juga, anak diajarkan untuk mengambil hikmah, kesimpulan dan pesan moral yang berbudi luhur tanpa merasa digurui, karena sebuah cerita lebih berkesan daripada sebuah nasehat murni atau tutur kata yang secara langsung disampaikan (Fitroh, 2015, p. 97).

Dari dua pendapat di atas dapat dimaknai bahwa dongeng merupakan suatu media yang efektif untuk membentuk karakter anak. Melalui dongeng anak-anak dapat mengambil inti sari berupa hikmah dari cerita yang disampaikan dan bisa membedakan mana yang baik dan yang buruk. Secara keseluruhan, dongeng di dalamnya terdapat tokoh prontagonis dan tokoh antagonis yakni antara tokoh yang baik dan tokoh yang jahat. Akhir dari sebuah cerita atau dongeng sudah dapat dipastikan setiap kebaikan akan menang melawan kejahatan. Nilai-nilai seperti ini secara tidak langsung sudah membentuk dan tertanam dalam benak pikiran anak, sehingga mereka berusaha untuk berbuat baik dalam kesehariannya.

Pentingnya kegiatan mendongeng sebagai sarana pembentukan karakter anak, maka penulis bersedia menjadi juri pada kegiatan lomba mendongeng yang diselenggarakan oleh Forum Koordinasi Pengelolaan Daerah Aliran Sungai Sumatera Selatan (Forum Das Sumsel) dalam rangka memperingati hari penanggulangan degradasi lahan dan kekeringan tahun 2020 dan hari lingkungan hidup tahun 2020 di objek wisata alam Punti Kayu Kota Palembang tepat sebelum pandemi corona virus menyebar ke Indonesia pada awal bulan maret 2020 . Di samping sebagai juri, penulis juga diberi kesempatan untuk memaparkan materi pelaksanaan dan capaian yang diperoleh dari kegiatan ini.

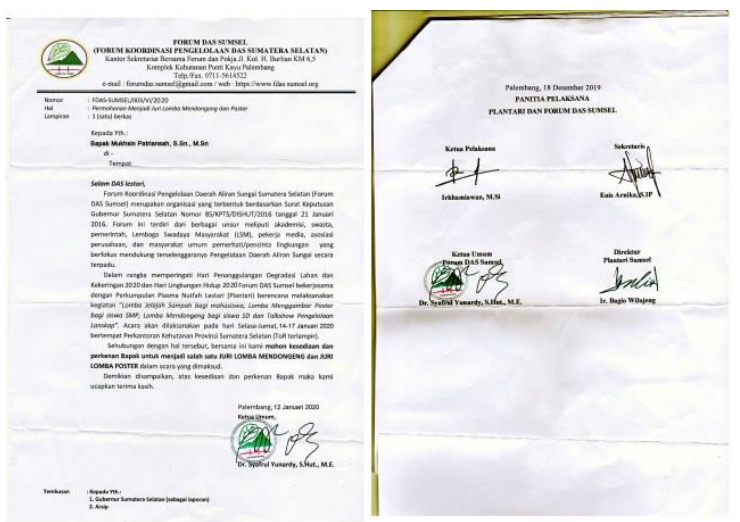

Gambar 1. Undangan kegiatan lomba mendongeng dari Forum Das Sumsel. (Sumber : Mukhsin Patriansah, 2020).

Melalui kegiatan ini diharapkan mampu mengoptimalisasi kepekaan anak terhadap persoalan lingkungan yang ada di Sumatera Selatan, khususnya di Kota Palembang. Peserta lomba yang mengikuti kegiatan ini merupakan perwakilan dari siswa-siswa terbaik dari setiap Sekolah Dasar yang tersebar diseluruh kota Palembang. Potensi yang dihasilkan dari kegiatan ini cukup menjanjikan, hal ini ditandai dengan antusiasme setiap sekolah dalam mengirimkan perwakilan siswanya yang memiliki bakat dan keterampilan dibidang mendongeng. Cerita atau dongeng yang disampaikan merupakan hasil dari buah pikiran peserta lomba itu sendiri.

Target capaian yang diperoleh dari kegiatan ini adalah sebagian besar peserta lomba sudah memahami karakter setiap tokoh di dalam dongeng yang disampaikan. Di samping itu, suara dan gerak tubuh serta emosi yang dipertunjukan cukup impresif sehingga pendengar dengan mudah menangkap isi pesan yang terkandung di dalam dongeng tersebut. Unsur terpenting yang menjadi penilaian dalam kegiatan lomba ini adalah nilainilai yang terkandung di dalamnya memiliki relasi dengan tema yang diusung yakni tentang lingkungan hidup.

Target capaian lain yang dihasilkan dari kegiatan ini adalah memberikan rangsangan kepada guru dan orang tua akan pentingnya penanaman karakter kepada anak melalui kegiatan bercerita atau mendongeng. Dengan demikian, pananaman karakter tidak hanya terfokus pada lingkungan pendidikan formal saja, tetapi juga melingkupi lingkungan pendidikan informal yakni dalam lingkungan keluarga dan masyarakat. di samping itu, kegiatan ini juga mampu memberikan nilai edukasi kepada guru dan orang tua agar selalu menanamkan karakter dalam diri mereka sendiri agar anak dapat melihat contoh secara 
langsung tentang sikap dan perbuatan yang baik.

\section{METODE}

Dalam Ensiklopedi Indonesia disebutkan bahwa, metodologi adalah ilmu tentang cara atau langkah untuk menganalisa sesuatu yang baru (Shadly, 1990, p. 45). Hal ini juga senada dengan pendapat Patriansah bahwa metode dapat diartikan juga sebagai suatu cara atau langkah-langkah yang dilakukan untuk menyelesaikan suatu permasalahan yang telah dirumuskan (Patriansah \& Yulius, 2021, p. 61). Dengan demikian, penggunaan suatu metode yang tepat sangat menentukan hasil yang diperoleh dalam kegiatan lomba mendongeng ini.

Berdasarkan analisa yang telah dilakukan, metode yang tepat dalam pelaksanaan kegiatan lomba mendongeng ini adalah sosialisasi, partisipatif dan penilaian serta evaluasi. Kegiatan ini dilaksanakan selama dua hari dengan rincian yakni di hari pertama memberikan sosialisasi dan partisipatif berupa pemaparan materi dan demonstrasi kepada peserta lomba bagaimana cara menyajikan dongeng yang benar. Peserta lomba yang ikut dalam kompetisi ini terdiri dari siswa dan siswi Sekolah Dasar yang duduk dibangku sekolah kelas 5 dan 6 . Kegiatan lomba mendongeng dilaksanakan dihari kedua dan dilanjutkan dengan penilaian dan evaluasi.

Sosialisai merupakan tahapan pertama yang dilaksanakan melalui pemaparan materi. Adapun materi yang disampaikan adalah cara membuat naskah dan teknik penyajian dongeng. Tahap kedua adalah partisipan berupa demonstrasi secara langsung kepada peserta lomba teknik-teknik mendongeng yang menarik. Selanjutnya, tahapan terakhir adalah penilaian dan evaluasi meliputi kesesuaian naskah dongeng dengan tema lomba, alur cerita yang singkat, jelas dan mudah dimengerti pesan yang disampaikan, bahasa dan gerak tubuh yang dilakukan saat mendongeng merupakan hal terpenting dalam penilaian. Evaluasi berupa kritikan dan saran yang diberikan kepada peserta lomba berkaitan dengan kekurangan dan kelemahan yang ditemukan saat mendongeng. Adapun kritikan dan saran yang diberikan secara umum bersifat membangun.

\section{HASIL DAN PEMBAHASAN Sosialisasi kegiatan lomba mendongeng}

Proses sosialisasi merupakan unsur terpenting dari kegiatan pengabdian kepada masyarakat, baik bersifat pelatihan, workshop ataupun kegiatan lomba. Kegiatan ini dilakukan dihari pertama dengan memberikan materimateri dasar mendongeng meliputi cara membuat naskah dan teknik penyajian dongeng. Membuat naskah merupakan hal terpenting dalam kegiatan mendongeng. Peserta lomba diwajibkan membuat naskah yang orisinal yakni tidak meniru naskah atau cerita dongeng yang sudah ada, namun demikian naskah yang dibuat memiliki relasi dengan tema yang sudah ditetapkan oleh tim panitia lomba yakni lingkungan hidup.

Dalam kesempatan ini penulis memberikan beberapa langkah dan cara membuat naskah dongeng yang baik di antaranya adalah pertama menentukan ide atau gagasan cerita. Gagasan dan ide berangkat dari persoalan lingkungan yang ada di sekitar kita seperti persoalan eksploitasi hutan, kebakaran hutan, sampah plasti, limbah industry dan lain sebagainya. Persoalanpersoalan ini bisa diambil dan dijadikan ide dalam membuat naskah dongeng. Kedua tentukan tokoh cerita di dalam naskah dongeng yang dibuat baik dari segi bentuk fisik, karakter, suara, atau sifat dan prilakunya. Pada umumnya nama tokoh mencerminkan sifat dan tingkah lakunya seperti tokoh malin kundang yang memiliki sifat sombong dan durhaka kepada orang tua, tokoh kancil dalam ceritanya merupakan hewan yang cerdik dan licik atau tokoh cerita pak belalang yang menggambarkan pria paruh baya yang pemalas.

Langkah ketiga, setelah tokoh utama ditentukan hal selanjutnya yang menjadi perhatian adalah menciptakan alur dan konflik di dalam dongeng yang dibuat. Alur dan konflik di dalam sebuah dongeng memiliki peranan yang sangat penting karena mampu membuat dongeng menjadi menarik. Sebagai contoh kisah cerita malin kundang yang awalnya hidup miskin dan serba kekurangan, kemudian dia merantau untuk merubah nasib hidupnya. Selama diperantauan si malin kundang menjadi orang kaya dan sukses. Malin kundang sama sekali tidak tahu kalau kesuksesan yang ia peroleh berkat do'a dari ibunya. Seketika dia melupakan itu semua dan tidak mengakui kalau orang tua tersebut adalah ibu kandung nya sendiri, akhirnya malin kundang menjadi anak durhaka dan dikutuk menjadi batu. Konflik semacam ini mampu membuat cerita lebih hidup dan menarik.

Selanjutnya, langkah keempat adalah menentukan setting cerita. Untuk setting cerita disesuaikan dengan kondisi lingkungan yang ada di Kota Palembang. Langkah kelima yakni menentukan kalimat yang digunakan dalam membuat naskah dongeng. Pastkan kalimat yang digunakan mudah dimengerti dan dipahami. Hindari kalimat yang multitafsir dan gunakan kalimat yang jelas serta lugas. 
Materi selanjutnya yang disosialisasikan kepada peserta lomba adalah teknik penyajian dongeng meliputi kesiapan peserta lomba dalam mengikuti kegiatan ini. Materi yang disampaikan di antaranya adalah menyiapkan mental agar peserta lomba tidak merasa canggung dan gugup ketika berada di atas panggung. Ciptakan suasana dan kondisi senyaman mungkin agar naskah dongeng yang diceritakan bisa disampaikan dengan baik dan jelas. Selanjutnya, karakter suara dan gerak tubuh saat menyampaikan dongeng. Suara dan gerak tubuh harus sesuai dengan peran atau karakter tokoh yang diceritakan, misalnya raksasa suaranya harus keras dan mampu menggambarkan bentuk raksasa yang memiliki tubuh besar. Ketika tokoh dalam dongeng tersebut sedang bersedih suara dan gerak tubuh juga mempu menggambarkan orang yang sedang bersedih. Siapkan alat peraga jika memang benar-benar dibutuhkan, alat peraga mampu membuat cerita atau dongeng lebih menarik. Alat peraga yang biasa digunakan dalam mendongeng misalnya seperti boneka, topeng, pedang, tongkat dan lain sebagainya.

\section{Proses Partisipatif}

Tahapan ini juga dilakukan pada hari pertama, tepatnya setelah pemaparan materi. Partisipatif lebih bersifat demonstrasi atau mempraktikan secara langsung kepada peserta lomba. Tujuan dari proses ini adalah agar peserta lomba benar-benar menguasai teknik penyajian dongeng yang menarik. Cara penyampaian sangat berpengaruh terhadap pesan yang disampaikan dalam sebuah dongeng. Seperti yang sudah dijelaskan ada beberapa teknik yang harus dikuasai perserta lomba di antaranya adalah menjaga sikap dan mental agar tidak gugup di atas panggung, menciptakan kondisi senyaman mungkin ketika berada di atas panggung, karakter suara dan gerak tubuh disaat menyampaikan cerita atau dongeng.

Selanjutnya proses partisipatif adalah melakukan suatu pembinaan kepada peserta lomba. pembinaan dapat dilakukan dengan cara membimbing secara langsung peserta lomba dalam melatih sikap dan mental mereka. Di samping itu, peserta lomba juga diberi arahan dan bimbingan dalam membuat naskah cerita atau dongeng yang akan disajikan dalam kegiatan lomba ini. Dengan demikian, peserta lomba mendapat pengalaman secara langsung bagaimana mengikuti suatu kompetisi mulai dari persiapan, membuat naskah hingga penyajian.

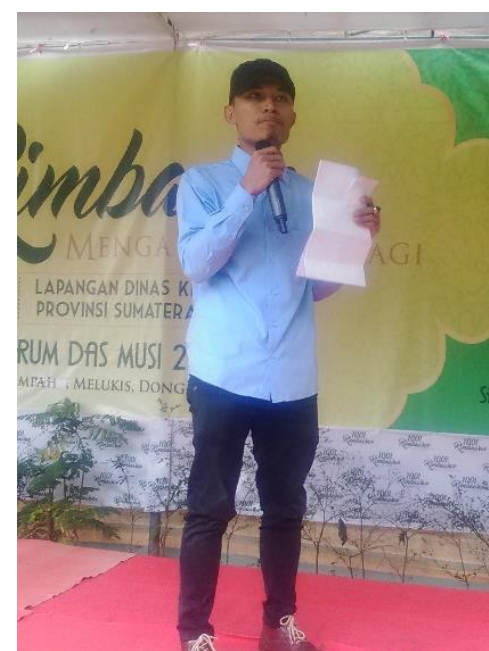

Gambar 2. Proses partisipatif kegiatan lomba mendongeng.

(Sumber foto : Didiek Prasetya, 2020).

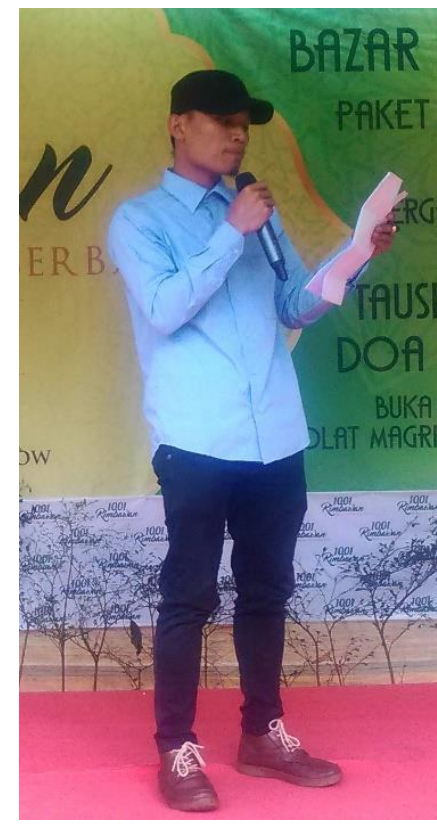

Gambar 3. Proses partisipatif kegiatan lomba mendongeng.

(Sumber foto : Didiek Prasetya, 2020).

\section{Kegiatan Lomba mendongeng}

Uraian sebelumnya menjelaskan bahwa kegiatan ini dilaksanakan oleh Forum Koordinasi Pengelolaan Daerah Aliran Sungai Sumatera Selatan (Forum Das Sumsel) dalam rangka memperingati hari penanggulangan degradasi lahan dan kekeringan tahun 2020 dan hari lingkungan hidup tahun 2020 di objek wisata alam Punti Kayu Kota Palembang yang berkerjasama dengan tim pengabdian pada masyarakat dari Universitas Indo Global Mandiri (UIGM) Palembang sebagai pemateri sekaligus menjadi dewan juri.

Tujuan dari kegiatan lomba mendongeng ini adalah sebagai salah satu upaya menanamkan etika dan moral kepada 
anak yang nantinya akan membentuk karakter mereka agar lebih peduli terhadap persoalanpersoalan yang berkaitan dengan lingkungan hidup, khususnya lingkungan di sekitar mereka sendiri, mulai dari lingkungan rumah ataupun sekolah. Sejatinya persoalan-persoalan yang berkaitan dengan lingkungan hidup sering dijumpai di sekitar kita, mulai dari membuang sampah sembarangan, pencemaran limbah industri, polusi udara yang disebabkan oleh kendaraan bermotor, eksploitasi lahan hutan secara berlebihan, kebakaran hutan yang mengakibatkan kabut asap dan lain sebagainya. Adapun kegiatan lomba ini diikuti oleh 20 peserta siswa dan siswi yang merupakan perwakilan dari Sekolah Dasar yang tersebar di Kota Pelembang. Namun demikian, ada juga sekolah yang tidak mengirimkan perwakilan siswanya dalam kegiatan ini. Masing-masing peserta lomba wajib mengikuti aturan-aturan yang sudah ditetapkan oleh tim panitia selama lomba berlangsung seperti tidak boleh berisik dan mengamati dengan seksama setiap peserta lomba yang tampil di atas panggung. Kegiatan lomba mendongeng ini dimulai dari pukul 09.00 wib sampai dengan selesai. Peserta lomba diwajibkan hadir sebelum waktu pelaksanaan lomba dimulai. Di samping itu, peserta lomba juga sudah mengenakan pakaian atau custom terlebih dahulu. Adapun durasi waktu yang ditetapkan kurang lebih 10 menit bagi peserta menyajikan atau membaca naskah dongeng yang sudah dibuat. Efesiensi waktu harus benar-benar dimanfaatkan oleh peserta lomba agar cerita atau dongeng yang disajikan dapat dimengerti dan ditangkap nilai pesan yang terkandung di dalamnya.

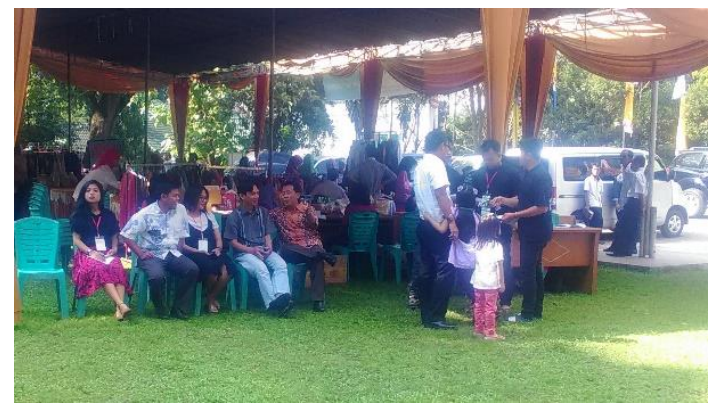

Gambar 4. Tim panitia lomba mendongeng beserta tamu undangan yang hadir (Sumber foto : Didiek Prasetya, 2020).

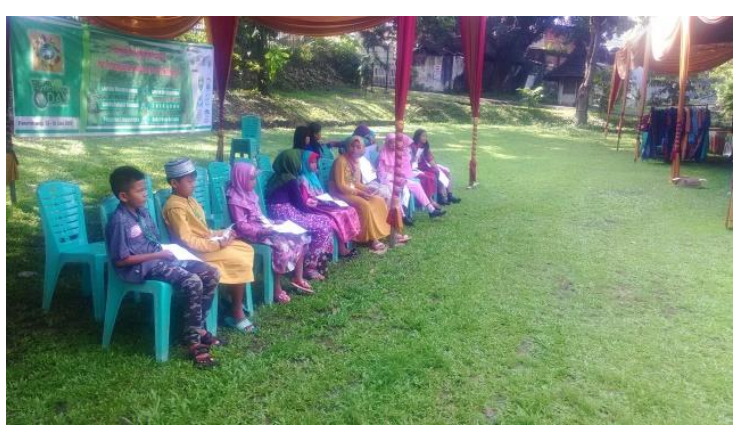

ambar 5. Peserta lomba yang hadir dalam kegiatan ini

(Sumber foto : Havis Aravik, 2020).

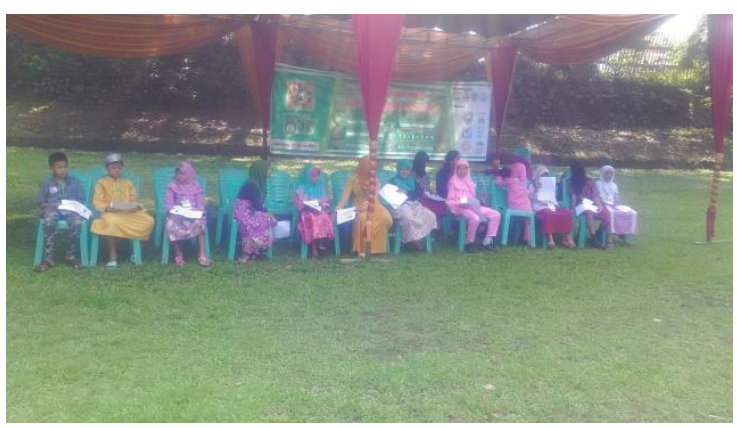

Gambar 6. Peserta lomba yang hadir dalam kegiatan ini

(Sumber foto : Havis Aravik, 2020).

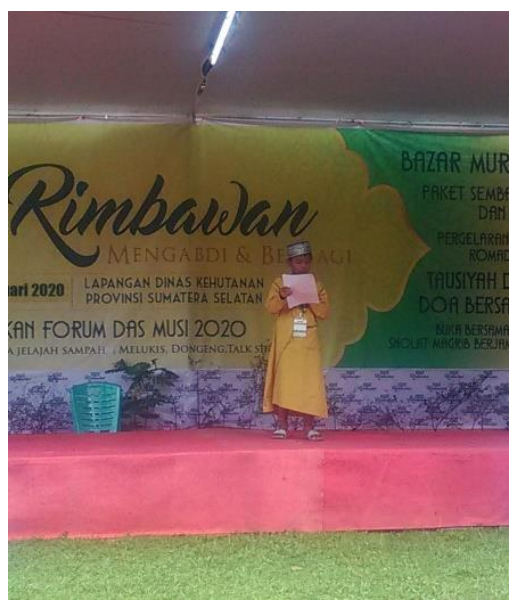

Gambar 7. Penyajian dongeng dari peserta lomba

(Sumber foto : Mukhsin Patriansah, 2020). 


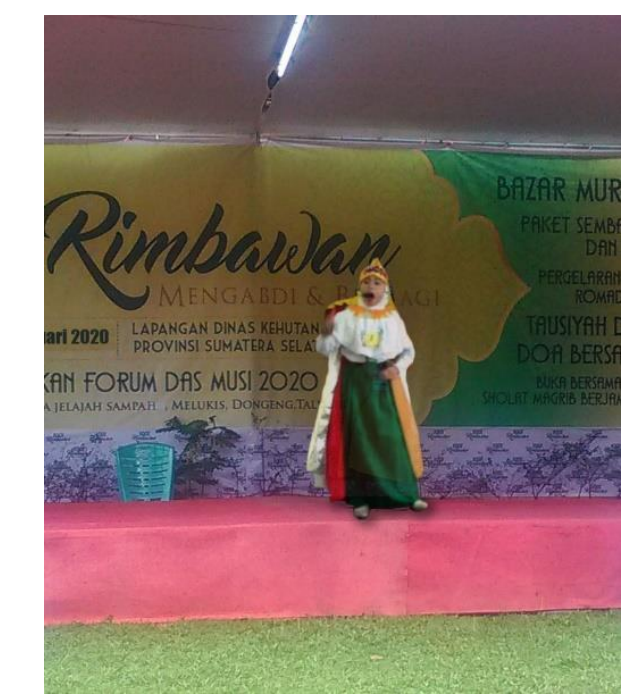

Gambar 8. Penyajian dongeng dari peserta lomba.

(Sumber foto : Mukhsin Patriansah, 2020).

\section{Penilaian dan evaluasi}

Penilaian dan evaluasi yang dilakukan berkaitan langsung dengan hal-hal yang harus dibenahi dan diperbaiki agar peserta lomba bisa melihat sejauh mana capaian yang mereka buat (Patriansah et al., 2021, p. 193). Penilaian dan evaluasi merupakan tahapan terakhir dari rangkaian kegiatan lomba mendongeng. Tim panitia memberikan penghargaan berupa piagam dan hadiah bagi peserta terbaik, hal ini bertujuan sebagai pemicu agar kegiatan yang dlaksanakan lebih kompetitif. Dengan demikian, anak-anak mampu mengeluarkan seluruh bakat dan kemampuannya dalam mendongeng. $\mathrm{Di}$ samping itu, kegiatan ini juga bertujuan memotivasi anak-anak agar lebih tertarik terhadap dongeng.

Ada dua aspek yang menjadi bahan penilaian dalam kegiatan lomba mendongeng ini, pertama aspek penilaian terhadap naskah cerita. Naskah cerita dapat dilihat dari gagasan dan ide yang berangkat dari persoalanpersoalan yang ada di sekitar kita dan memiliki relasi terhadap tema kegiatan. Selain itu, bagaimana peran dan karakter tokoh-tokoh di dalam naskah dongeng yang dibuat. Alur dan konflik yang dihadirkan dalam cerita juga menjadi bahan penilaian dari kegiatan ini. Selanjutnya, penggunaan kalimat yang jelas dan lugas juga menjadi bahan penilaian dari dewan juri. Penggunaan kalimat yang jelas sangat berpengaruh terhadap interpretasi dan tanggapan orang yang mendengar.

Aspek kedua yang dinilai adalah teknik penyajian dongeng. Dewan juri menilai dari segi sikap dan mental peserta saat berada di atas panggung, sikap yang baik dan mental yang kuat menjadi nilai plus bagi peserta. Selanjutnya, penilaian dapat dilihat dari karakter suara dan gerak tubuh saat menyampaikan dongeng. Karakter suara dan gerak tubuh mampu membuat dongeng menjadi lebih hidup, sehingga penonton terbawa suasana saat mendengarkan dongeng yang disajikan. Dewan juri akan melihat dan menilai sejauh mana peserta lomba mampu membuat isi cerita yang ia baca menjadi lebih hidup dan menarik.

Sebagian besar peserta lomba mampu menampilkan pertunjukan yang menarik dan memiliki sikap dan mental yang kuat saat di atas panggung. Walaupun demikian, ada juga terdapat sebagian kecil dari peserta lomba yang merasa gugup dan kaku, hal ini dapat dimaklumi karena anak seumuran mereka sudah berani maju dan tampil di atas panggung merupakan sesuatu yang patut diapresiasi. Di samping itu, naskah cerita atau dongeng yang dibuat merupakan naskah yang orisinal yakni naskah yang dibuat berdasarkan gagasan dan ide dari peserta lomba. secara keseluruhan naskah dongeng yang dibuat cukup menarik dan memiliki relasi terhadap tema yang sudah ditetapkan oleh tim panitia.

\section{SIMPULAN DAN SARAN}

Selama rangkaian kegiatan ini berlangsung mulai dari proses sosialisasi, partisipatif hingga proses penilaian dan evaluasi mendapatkan hasil yang positif yakni tingginya animo peserta lomba untuk belajar membuat naskah dongeng dan sebagian besar peserta lomba memiliki sikap dan mental yang kuat saat berada di atas panggung. Kegiatan ini juga mendapatkan apresiasi dari para guru dan orang tua yang hadir sebagai tamu undangan. Bagi mereka ada suatu kebanggaan ketika melihat anak-anaknya tampil di atas panggung. Melalui kegiatan mendongeng ini diharapkan mampu membentuk karakter anak yang memiliki etika dan moral yang baik. Sejatinya anak merupakan generasi penerus bangsa, hal ini perlu ditanamkan etika dan moral sedini mungkin agar ke depannya mereka menjadi manusia yang berbudi luhur. Di samping itu, melalui kegiatan ini diharapkan mampu menjadi pemicu bagi para guru dan orang tua untuk mendidik anaknya dengan memberikan contoh secara langsung kepada mereka untuk berbuat baik bagi sesama manusia ataupun alam semesta.

Kegiatan mendongeng memiliki andil yang cukup besar terhadap pembentukan karakter anak. Harapannya, kegiatan lomba mendongeng ini dilakukan secara kontinu dan berkelanjutan agar mampu mengembangkan bakat dan kemampuan anak-anak dalam menulis naskah dongeng dan menyajikannya di atas panggung. 


\section{DAFTAR RUJUKAN}

Cahyani, Nu., \& Raharjo, T. J. (2021). Implementasi Pendidikan Karakter melalui Pembiasaan di PAUD Sekolah Alam Ungaran. Lifelong Education Journal, 1(1), 53-65.

https://journal.imadiklus.or.id/index.php/le $\mathrm{j} /$ article/view/15

Fitroh, S. F. (2015). Dongeng Sebagai Media Penanaman Karakter Pada Anak Usia Dini. Universitas Trunojoyo Madura, 2, 76-149.

Narwanti, S. (2011). Pendidikan Karakter Pengintegrasian 18 Nilai Pembentukan Karakter dalam Mata Pelajaran. Familia (Group Relasi Inti Media).

Patriansah, M., Halim, B., \& Putra, M. E. P. (2021). MENINGKATKAN KREATIVITAS SISWA MELALUI KEGIATAN LOMBA GAMBAR BERCERITA DI SD 226 PALEMBANG. 4(April), 188-194.

Patriansah, M., \& Yulius, Y. (2021). Upaya Meningkatkan Perekonomian Warga Desa melalui Pelatihan Kerajinan Bunga dari Akar Kayu. 5(01), 58-66.

Shadly, H. (1990). Ensiklopedi Nasional Indonesia. Jakarta : PT. Cipta Adi Pustaka.

Suwartini, S. (2017). Pendidikan Karakter dan Pembangunan Sumber Daya Manusia Keberlanjutan. Jurnal Pendidikan, 4(1), 220-234.

https://media.neliti.com/media/publication s/259090-pendidikan-karakter-danpembangunan-sumb-e0cf1b5a.pdf

Utomo, S. B. (2019). MENDONGENG DALAM PERSPEKTIF PENDIDIKAN. Angewandte Chemie International Edition, 6(11), 951-952., 11-28. 